
saline spring water was boiled to concentrate its mineral wealth. The painting shows the profound impact that this industry had already made on its surroundings. "It consumed enormous amounts of firewood," says Högselius. "The area has been totally deforested." Yet the lack of convenient fuel seems not to have affected the prosperous medieval city. The clue is in the river that flows through it, carrying huge log booms into Schwäbisch Hall. "When it faced local scarcity of firewood, it didn't make a transition to another fuel," he explains. Schwäbisch Hall looked for other sources of wood, so that its industry could continue in the same way as before.

The lesson, says Högselius, is that energy sources gather social and economic momentum - webs of local investment that create vested interests, cultural habits and trade interdependencies that maintain the status quo. "The process of scaling up takes decades, and over time the momentum accumulates," he says. "Once you have embarked on that kind of path, there's a logic of its own to continue it."

That momentum presents a barrier to change, which is why new energy sources often require a crisis before they can gain a foothold. Coal ultimately overtook wood in Europe, China and much of the world after industrial growth had stripped the forests and global shipping made the fossil fuel more widely available. Further crises provided opportunities for natural-gas, hydroelectric and nuclear power plants that, together with coal, produce most of today's electricity (see page S134). But not everyone perceived these events as crises, and even if they did, different groups pursued their own, sometimes counter-intuitive agendas. "It's a myth to say that energy mixes are somehow naturally emerging," says Petra Dolata, an energy historian at the University of Calgary in Canada. "There's a lot of economic and political activity going on. People tend to underestimate the importance of that." Even the most climate-conscious are not immune. "The very same Germany that is so proud of its transition to renewables is still advancing coal frontiers in the Ruhr area," says Högselius. "Many people are employed in this industry."

\section{GETTING SCIENTIFIC}

Energy planners hope for more logical paths for the low-carbon future. Economists are working to put a price on things like the health and environmental impacts of coal combustion, thus mathematizing some of the social and political concerns that guide power-plant selection (see page S145). Energy modellers, meanwhile, are crafting increasingly sophisticated tools for optimizing the placement of solar panels, wind turbines and other variablepower equipment, as well as the transmission lines that distribute their output.

Modellers say that optimizing renewable energy on a continental scale is crucial to ensuring that variable, weather-dependent

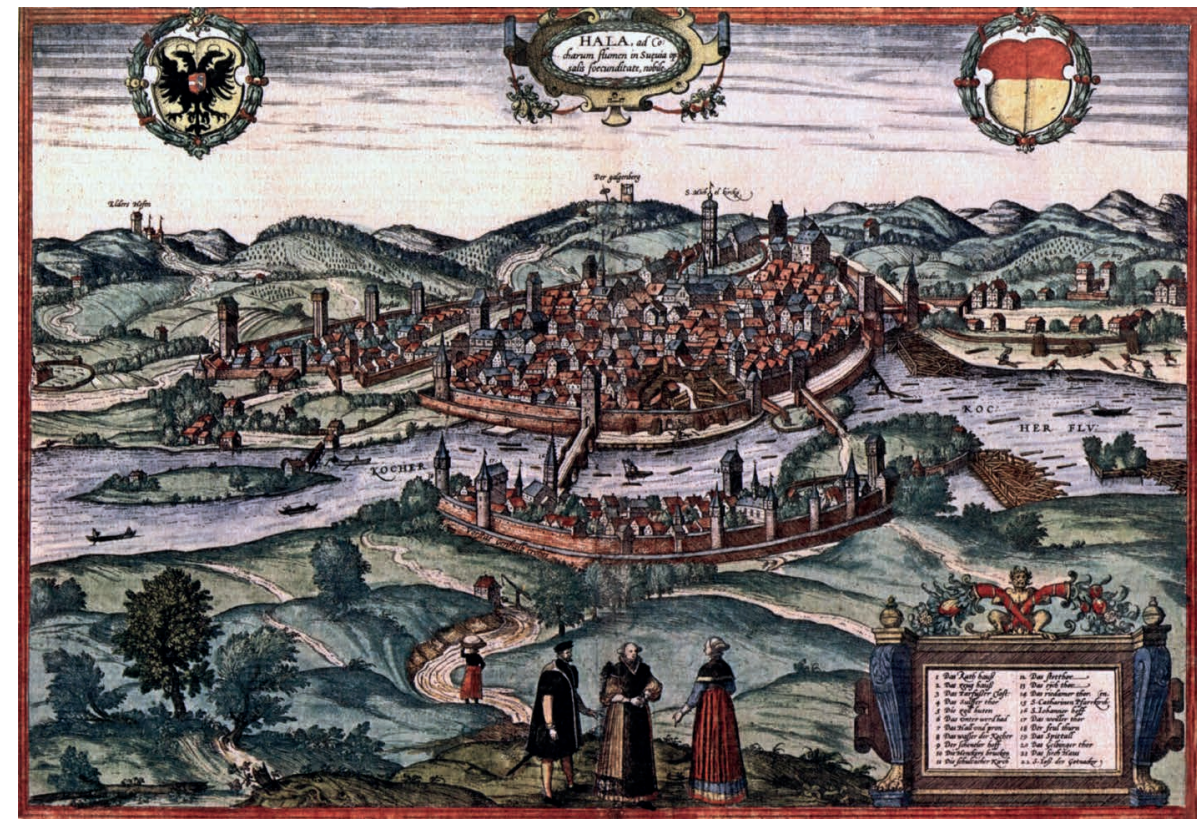

Schwäbisch Hall by Frans Hogenberg. The town used firewood long after the hills were deforested.

energy sources can be reliable and cost-effective. Consider the projection published last year by researchers at the US National Oceanic and Atmospheric Administration (NOAA; A. E. MacDonald et al. Nature Clim. Change 6, 526-531; 2016). According to the authors, cooptimized siting of solar and wind generators and power lines minimizes the need for batteries or for nuclear or fossil-fuel power plants to back up the renewable energy supply. "We can find locations that can back each other up," says Christopher Clack, a co-author of the study who is now chief executive of the power-gridmodelling firm Vibrant Clean Energy in Erie, Colorado. "If you've got a big market or region that you can share to, you will be able to reduce emissions and costs at the same time."

The co-optimized siting idea came from Europe. German energy consultant Gregor Czisch showed that wind power from North Africa and the Middle East, which peaks in the summer, could balance wind power from Northern Europe, which peaks in the winter. Czisch developed his co-optimization methods during thesis work at the University of Kassel in Germany, and he began publishing his results in 2001. By 2004, he was showing that weather-driven optimization could enable renewable energy to cost-effectively meet $100 \%$ of the power needs of more than 50 nations (containing more than 1.1 billion people) in Europe, North Africa and the Middle East.

Czisch's scenarios rely on several hundred thousand wind turbines, supported by biomass power plants and existing hydropower reservoirs. He also specifies a network of power lines carrying direct current (DC), which is more efficient over long distances than alternating current (AC), to share output between regions.

The NOAA study focuses on the United States in 2030. The authors' scenario maximizes greenhouse-gas reduction by concentrating on wind power and large arrays of solar panels (which were too costly when Czisch was crafting his optimizations more than a decade ago) as well as some natural-gas and nuclear plants.

The results are striking: this network would slash the greenhouse gases emitted by US power production by up to $79 \%$, and also slightly reduce the average power cost. Clack says that scenarios generated with his firm's latest optimization model (WIS:dom) show an $84 \%$ reduction.

A team of Canadian, US and Mexican scientists is trying something even more ambitious: an optimization plan for the whole continent, to be completed by 2019. Clack says this North American Renewable Integration Study, for which he is technical reviewer, is "like our Nature Climate Change study but on steroids".

Ambitious US power-optimization plans that require installation of thousands of miles of power lines have yet to be embraced by either the federal government or the state utility regulators that traditionally control the transmission network. The regulators' reluctance is often due to their fear that local generators may face greater competition from the new power lines that bring in electricity from elsewhere. Brendan Kirby, an expert in renewable energy and grid integration who consults for the US National Renewable Energy Laboratory in Golden, Colorado, says 'not-in-my-backyard' thinking and opposing interests make it a challenge to build even discrete power lines in the United States. "The problem with a new continental network is that you just can't build it," says Kirby.

Similar tussles are going on all over the world. Grid operators in Germany are still struggling to complete the siting of three DC power lines approved by the government in 
2013 as part of the Energiewende ('energy transition'). Local communities are opposed to their land being bisected by large cables and towers.

\section{STATE POWER IN CHINA}

In contrast with the United States, China has an authoritarian central government that exerts strong control over Chinese society, including the power industry. One would imagine that this level of control would position China for rapid implementation of renewable energy, which the central government professes to strongly support. Yet, even here, social and political pressures muddy the waters - and China's energy transition is not screaming past that of the United States.

Most of China's power grids are operated by the State Grid Corporation of China (SGCC), which is the world's largest electric utility company. The SGCC dwarfs its US rivals, with 2015 revenues roughly 14 times those of Duke Energy, the largest US utility company. And because the SGCC determines how much electricity each power plant is allowed to sell, it wields immense power, says Chi-Jen Yang, author of the 2017 book Energy Policy in China (Routledge) and an independent consultant.

So far, renewable power plants in China seem to be getting the short end of the stick. To deal with congestion on its power lines, the SGCC frequently orders wind, solar and hydropower plants to shut down in favour of coal. It often cites a need to maintain grid stability, but Yang says the SGCC's policies also protect the coal plants' revenues - reflecting other pro-coal moves by Beijing, such as sustaining carbonintensive plants that convert coal into chemicals and liquid fuels. "The central government has strong financial stakes in the coal industry," he says, "and has been actively intervening in the market to protect the profitability of coal."

In 2015, deliberate 'curtailment' squandered $15 \%$ of China's potential wind-power generation - almost equivalent to all the wind energy generated in the United Kingdom that year - and about $10 \%$ of potential solar generation. Curtailment is a big reason why China's renewable-energy plants deliver lacklustre performance. At the end of 2015, China had nearly twice as much wind-generation capacity as the United States, yet delivered less wind energy.

Despite promised reforms from Beijing, the situation remains challenging for renewable generators. Solar curtailment increased by $50 \%$ between 2015 and 2016, according to the global environment charity Greenpeace. To avoid increased curtailment, officials in Beijing have ordered a moratorium on new wind farms in Gansu and five other regions.

Yang says the SGCC could expand its network to fix the problem. In fact, the giant firm is rapidly adding DC power lines, thanks to its ability to override any local opposition. However, the lines were not designed with wind and solar power in mind. Most recently completed lines, says Yang, are to deliver coal-fired power from northern China to eastern cities such as Beijing, which have shut down local power plants to address civic protests over foul air.

Renewable-energy developers do have some room to manoeuvre. For example, Yang says windpower growth is shifting from the north and west to onshore and offshore projects in China's eastern provinces. Putting wind power closer to the eastern megacities thus reduces dependence on long-distance power lines.

Nevertheless, he views China's clean-energy transition as more fragile than that in the United States. Whereas market forces, state policies and corporate purchasing continue to drive solar and wind deployment forward in the United States - despite a hostile federal government - the greater central control in China means renewable power's momentum may be "quite reversible", says Yang.

\section{POWER MYTHS}

Power-grid politics and culture have an equally interesting trajectory in India, where several hundred million people currently live without grid access. Small independent solar systems offer a potential shortcut to electrical service for these mostly rural households - along with roughly 1 billion more similarly 'powerless' peoples in other countries across south Asia, sub-Saharan Africa and South America (see page S148).

To succeed, however, solar entrepreneurs and those backing them must overcome the "mythology" of the grid, says anthropologist Jamie Cross of the University of Edinburgh, UK. "Even in places where the main electricity grid is actually quite poor, providing people with electricity on an irregular basis and beset with faults and surges and blackouts," he says, "people remain quite invested in the grid and their connection to it."

Cross says that across the "Global South" (his preferred term for developing nations, economically delayed by colonialism and globalization), big energy projects are viewed as a means of restoring economic independence. India's first prime minister, Jawaharlal Nehru, famously called hydroelectric megadams the "temples of modern India”. More than 60 years later, India's renewable-power options have expanded greatly. Entrepreneurial innovation has delivered a spectrum of local solar-power options, from handheld lanterns to village microgrids, that offer an immediate alternative to the grid connections for which rural people have waited in vain for decades. "There are many more sophisticated models for decentralized power generation in the Global South right now than there are in the Global North," says Cross.

Yet the grid continues to cast a large shadow on these stand-alone solutions. Solar microgrids offer less-intense current than the grid, doing little more than charging mobile phones and powering a few lights. Cross refers to a village in India's Bihar state, where residents rejected a solar microgrid from Greenpeace in 2014, chanting, "We want real electricity, not fake electricity!"

Cross, who is writing a book about solar lanterns, saw the grid's allure firsthand when working in the powerless hamlet of Goudaguda in Odisha state. Goudaguda is settled by Poraja Adivasis - indigenous people who rank among India's most marginalized. The Adivasi felt that their power connection had been blocked by the area's high-caste residents, who got their own grid links in 1984. "Against that backdrop you can imagine what the grid connection might mean," says Cross. "It signifies that you are recognized in the eyes of the state as equal citizens." A grid connection, he adds, "ties you to the state and to the wider nation".

Mythology can be just as powerful in the Global North, as evidenced by the way that Swansea Bay's proposed tidal barrage has captured the local imagination. The project has become a symbol of revival for Wales - a first test for innovative technology that could reinvigorate the former coal-mining region.

When the UK government granted planning permission for the project in 2015, Swansea Council leader Rob Stewart predicted the barrage would "put Swansea on the map as an exemplar for renewable energy production". Carolyn Harris, the Labour member of Parliament for Swansea East, said the "innovative green energy scheme" had lit a fire locally in Swansea just as it had "captured ministers" imagination" in London.

More than two years later, however, the government is still considering the level of subsidies to award to the $£ 1.3$-billion (US\$1.7-billion) project. How much of the investment risk the government can or should absorb to make innovative, popular and renewable technology a reality is just one more of those social questions that - unfortunately for politicians - cannot be answered by models.

Peter Fairley is a freelance science writer based in Victoria, Canada. 